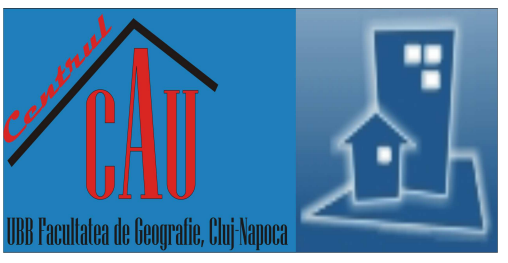

\title{
Guest Editorial \\ Territorial Identities and Heritage. A Constructivist Approach
}

\author{
Oana-Ramona ILOVAN ${ }^{1}$, Marinela ISTRATE ${ }^{*_{2}}$ \\ *Corresponding author \\ ${ }^{1}$ Babeș-Bolyai University, Faculty of Geography, Department of Regional Geography and Territorial Planning, Territorial Identities \\ and Development Research Centre, Cluj-Napoca, ROMANIA \\ 2 "Al. I. Cuza” University of Iaşi, Faculty of Geography and Geology, Department of Geography, Iaşi, ROMANIA \\ $\triangle$ oana.ilovan@ubbcluj.ro (iD https://orcid.org/oooo-0oo3-2075-1808 \\ $\triangle$ istrate.marinela@uaic.ro (iD https://orcid.org/oooo-0oo2-1456-6772 \\ DOI: 10.24193/JSSPSI.2021.7.01 \\ https://doi.org/10.24193/JSSPSI.2021.7.01
}

K e y w o r d s: representations, cultural landscape, social construction, place attachment, territorial planning, development

\begin{abstract}
A B S T RA C T
Territorial identity is defined by tangible and intangible features and involves both place attachment and belonging and the politics of territorial planning. When considered as an expression of historical heritage and characteristics, shared by settled collectivities, territorial identity in all its declinations (urban, local, regional, national) can be considered a tool against the current and stronger homogenising effects of globalisation. At the same time, local identity harbours the emotional and symbolic meanings people ascribe to a sense of self and attachment to place. We advocate for a relational, dynamic, and participatory notion of territorial identity, constituted both spatially and socially, challenging the notion of identity as fixed, natural, ahistorical, or rooted in a certain essence. Besides territorial identity, another key concept discussed is landscape, conceived as a social construct and signifying system, in its morphological (i.e. material form) and/or in its ideological or represented aspects. In a certain sense, the following articles can be considered a contribution both to territorial identity and landscape studies, through the lenses of New Cultural Geography, showing how territorial identities are constructed at the intersection of spatial and social relations, embedded in various networks of power. Understanding territorial identities as dynamic products and processes, historically and geographically contingent, formed and enacted, is part of our making sense of the world and planning for a better future.
\end{abstract}

Territorial identity is defined by tangible and intangible features and involves both place attachment and belonging and the politics of territorial planning (Banini and Ilovan, 2021c; Ilovan, 2021). When considered as an expression of historical heritage and characteristics, shared by settled collectivities, territorial identity in all its declinations (urban, local, regional, national) can be considered a tool against the current and stronger homogenising effects of globalisation. However, one should consider that local responses could be different to the influence of the same factors (Castree, 2009). Concurrently, territorial identity harbours the emotional and symbolic meanings people ascribe to a sense of self and attachment to place (Banini, 2021).

Beside attracting scientific interest, the theme of identity/identities has been on the European 
Commission's research agenda starting with the 1990 . Funded research projects paid attention to processes of identity formation and identification with the European Union, showcasing the role of cultural heritage, memorialisation and cherishing of legacies, collective action, participatory processes, of inclusion and exclusion, etc. in the (re)construction of identities at the individual and collective levels and in contributing to enhancing territorial identities (European Commission and Miller, 2012).

This special issue starts from a relational, dynamic, and participatory notion of territorial identity (Banini, 2017; Banini, Ilovan, 2021a, 2021b; Paasi, 2021), constituted both spatially and socially, challenging the notion of identity as fixed, natural, ahistorical, or rooted in a certain essence. Therefore, it hosts the results of original empirical and theoretical scientific research on territorial identity and its representations as constructed through discourses and practices.

We welcomed contributions on the following topics of interest, but not limited to these: representations of territorial identity and development discourses, images, practices; heritage management; perceptions of territorial identity at various levels; constructing, preserving and promoting territorial identities; place/regional attachment in time; (re)defining place meaning and topophilia; territorial identity and territorial planning; territorial identity and public policy; territorial identity and formal and informal education; theoretical contributions for the study of territorial identity within the discourse of Cultural Geography; research methodology for the study of territorial identity.

These topics are congruent with the directions within the research programme carried out at the Territorial Identities and Development Research Centre (TIDRC, 2020), both editors being its members, and within its scientific journal, Territorial Identity and Development.

In our Call for Papers, we addressed quite a wide range of topics. However, all are covered in this special issue and the six articles manage to provide readers with various perspectives on territorial identities and heritage, from several countries (i.e. Italy, Poland, Romania), on both the urban and rural areas, showcasing the local and the regional scales.

Four articles focus on practices and discourses of constructing the territorial identity of the urban area. The first of these is authored by Amalia Niţă, who chooses the case study of Craiova city, in Romania, to assess its urban image, by adapting the Lynch method. Dr. Niţă argues that a successful city is based also on inhabitants' mental images of the area. In this framework, their perceptions and representations of the urban area are explored through interviews, then complemented by aerial images, leading the author to conclude that urban sustainable planning and development are possible if one considers a mixture between the fine grain and coarse grain layout of the urban fabric (Niţă, 2021).

Drawing on the theme of representations of the urban area, in the second article, Oana-Ramona Ilovan and Florentina-Cristina Merciu discuss the politics of symbolic representation in visual imagery produced during socialist Romania (1948-1989). Official visual materials (i.e. Geography school textbooks and picture postcards) and accompanying texts undergo discourse analysis and critical visual methodology. The authors show how these representations fit into the metanarrative of socialist propaganda. The urban identity of the Romanian Danubian settlements is constructed and then deconstructed exhibiting the symbols and stories embedded in the represented cultural landscapes. Similar to previous research (Ilovan, 2020), the authors emphasise the societal relevance of not taking for granted the visually represented power relations, the heritage, and the connection between past and present (Ilovan and Merciu, 2021).

Heritage is discussed in the third article through statues as artefacts, acknowledged or contested, depending on changing political realities in the city of Czernowitz/Cernăuți/Chernovtsy/Chernivtsi, in Bukovina, Romania. Ştefan Purici and Harieta Mareci Sabol research the transformation of the urban main squares, their symbols and visual representations, the related practices and discourses, concluding that such monuments, as identity markers, "transform memory - despite its ephemeral and fluid characters into a continuous present" (Purici and Mareci Sabol, 2021, p. 51).

The fourth article on city image and urban identities is authored by Cezara Ionela Dulce and Ionel Muntele. They analyse Erasmus+ student mobility and internships as premises for improving the image of the university centre of Iaşi and its attractiveness, alongside the cultural assets of the city, as presented in the article, all this in the larger context of educational tourism (Dulce and Muntele, 2021).

Representations of place, narratives and place attachment are further approached by a research article on the rural areas of Poland. Paulina Tobiasz-Lis and Marcin Wójcik build their research on several examples from the Polish countryside to show which are the "anchors" of its territorial identity.

Inhabitants' perceptions of their living space, the meanings they attach to places are considered in a trial to identify general patterns of transforming space into a place (Tobiasz-Lis and Wójcik, 2021, p. 65). Authors identify four categories of "anchors" involved into this process, which they discuss from the perspective of the cultural approach within rural geography. 


\section{Guest Editorial Territorial Identities and Heritage. A Constructivist Approach Journal of Settlements and Spatial Planning, Special Issue, no. 7 (2021) 1-4 Territorial Identities and Heritage. Discourses and Practices}

The article closing this special issue offers readers a series of valuable insights into the Italian context concerning regional landscape planning and local planning. Anna Maria Colavitti and Sergio Serra discuss several case studies in Italy, questioning the multilevel governance of cultural heritage and the current situation of inter-institutional cooperation and citizen participation that could lead to an integrated planning approach. The ineffectiveness of landscape plans and policies is an issue that needs to be addressed shortly as it impacts profoundly territorial government and results, many times, into a clash between "conservative measures and transformation drivers" (Colavitti and Serra, 2021, p. 81).

To sum up, the notion of territorial identity discussed in the following papers joins together the material and the symbolic, the relational and the political, just as Morin (2009) stated for landscape, conceived as a social construct and signifying system, in its morphological and/or in its ideological or represented aspects: "landscapes carry symbolic or ideological meanings that reflect back and help produce social practices, lived relationships and social identities, and also become sites of claiming or contesting authority over an area. Social practices and landscapes mutually constitute one other in an ongoing fashion" (Morin, 2009, p. 297).

Such research could and should support the decisions of the policy community in education, culture, heritage management, territorial planning and development (Bănică and Istrate, 2012; Dulamă, Maroşi and Ilovan 2016; Ilovan, 2016, 2017; Maroși et al., 2019; Răcăşan and Egresi, 2019; Zotic and Alexandru, 2015). Policies should focus on the individual, on settled collectivities and territorial identities, thus being closely connected to human culture and heritage, to geographically-based identities (Banini, 2021; Banini and Ilovan, 2021c; Ilovan, 2021).

In a certain sense, the following articles can be considered a contribution both to territorial identity and landscape studies, through the lenses of New Cultural Geography, showing how territorial identities and landscapes are constructed at the intersection of spatial and social relations, embedded in various networks of power. Understanding territorial identities as dynamic products and processes, historically and geographically contingent, formed and enacted, is part of our making sense of the world and planning for a better future.

\section{ACKNOWLEDGEMENTS}

We thank Vasile Zotic and Diana-Elena Alexandru, from the editorial team of Journal of Settlements and Spatial Planning, for their support to convey this issue. Moreover, we are grateful to all our colleagues from Romania and abroad who reviewed submissions.

\section{REFERENCES}

Bănică A., Istrate M. (2012), Urban identities in peripheral spaces: The Carpathian small towns in Romania. Analele Universităţii din Oradea, Seria Geografie, 262-272.

Banini T. (2017), Proposing a theoretical framework for local territorial identities: concepts, questions and pitfalls. Territorial Identity and Development, 2(2), 1623. DOI:10.23740/TID220172

Banini T. (2021), Chapter 1. Towards a methodology for constructing local territorial identities. In: Ilovan O.-R. (ed.), Territorial Identities in Action. Presa Universitară Clujeană, Cluj-Napoca, 13-39.

Banini T., Ilovan O.-R. (2021a), Conclusions: towards a new agenda for place/territorial identity research. In: Banini T., Ilovan O.-R. (eds.), Representing Place and Territorial Identities in Europe. GeoJournal Library, vol. 127. Springer, Cham, 251-265, https://doi.org/10.1007/978-3-030-66766-5_17

Banini T., Ilovan O.-R. (2021b), Introduction: dealing with territorial/place identity representations. In: Banini T., Ilovan O.-R. (eds.), Representing Place and Territorial Identities in Europe. GeoJournal Library, vol. 127. Springer, Cham, 1-19. https://doi.org/10.1007/978-3-030-66766-5_1

Banini T., Ilovan O.-R. (eds.) (2021c), Representing Place and Territorial Identities in Europe. GeoJournal Library, vol. 127. Springer, Cham.

Castree N. (2009), Place: Connections and boundaries in an interdependent world. In: Clifford N. J., Holloway S. L., Rice S. P., Valentine G. (eds.), Key Concepts in Geography. Sage, London, Thousand Oaks, New Delhi, Singapore, 153-172.

Colavitti A. M., Serra S. (2021), Regional landscape planning and local planning. Insights from the Italian context. Journal of Settlements and Spatial Planning, Special Issue 7, 81-91. DOI: 10.24193/JSSPSI.2021.7.07 Dulamă M. E., Maroşi Z., Ilovan O.-R. (2016), Chapter 3: Geography university education for the protection and capitalisation of cultural urban landscapes. A case study: The Museum Square, Cluj-Napoca, Romania. In: Ilovan O.-R., Dulamă M.E. (eds.), Territorial Identity and Values in Geographical Education. Presa Universitară Clujeană, Cluj-Napoca, 59-118.

Dulce C. I., Muntele I. (2021), Student mobility attractiveness and premise of improving the city image. Case study: Alexandru Ioan Cuza University of Iași. Journal of Settlements and Spatial Planning, Special Issue 7, 73-80. DOI: 10.24193/JSSPSI.2021.7.06

European Commission, Miller R. (2012), The Development of European Identity/Identities: Unfinished Business. A Policy Review. DirectorateGeneral for Research and Innovation, Socio-Economic Sciences and Humanities. URL: http://www.melaproject.polimi.it/upl/cms/attach/20120906/175214213 _9680.pdf. Accessed on 23.05.2021. 
Ilovan O.-R. (2020), The development discourse during socialist Romania in visual representations of the urban area. Journal of Urban History, 1-35. DOI: 10.1177/0096144220982957

Ilovan O.-R. (ed.) (2021), Territorial Identities in Action. Presa Universitară Clujeană, Cluj-Napoca. URL: http://www.editura.ubbcluj.ro/bd/ebooks/pdf/2927.pd f. Accessed on 21.06.2021.

Ilovan O.-R., Doroftei I., Buş R. M., Kosinszki S.-A. (2016), Chapter 1: Territorial identity, cultural landscapes and values education. A brief approach. In: Ilovan O.-R., Dulamă M.E. (eds.), Territorial Identity and Values in Geographical Education. Presa Universitară Clujeană, Cluj-Napoca, 13-30.

Ilovan O.-R., Dulamă M. E., Boţan C. N., Ciascai L., Fonogea S.-F., Rus G. M. (2017), Meaningful learning: case studies on the territorial identity of historical urban centres. In: Chis V., Albulescu I. (eds.), $5^{\text {th }}$ ERD Conference, European Proceedings of Social and Behavioural Sciences, 41, 413-421. DOI: 10.15405/epsbs.2018.06.49

Ilovan O.-R., Merciu F.-C. (2021), Building visual intertextuality and territorial identities for the Romanian Danubian settlements during socialism. Journal of Settlements and Spatial Planning, Special Issue 7, 15-5O. DOI: 10.24193/JSSPSI.2021.7.03

Maroși Z., Adorean E.-C., Ilovan O.-R., Gligor V., Voicu C.-G., Nicula A.-S., Dulamă M. E. (2019), Living the urban cultural landscapes in the city centre of Cluj-Napoca/ Kolozsvár/ Klausenburg, Romania. Mitteilungen der Österreichischen Geographischen Gesellschaft, 161, 117-160. DOI: 10.1553/moegg161s117
Morin, M. K. (2009), Landscape: representing and interpreting the world. In: Clifford N. J., Holloway S. L., Rice S. P., Valentine G. (eds.), Key Concepts in Geography. Sage, London, Thousand Oaks, New Delhi, Singapore, 286-299.

Niţă A. (2021), Rethinking Lynch's “The Image of the City" model in the context of urban fabric dynamics. Case study: Craiova, Romania. Journal of Settlements and Spatial Planning, Special Issue 7, 5-14. DOI: 10.24193/JSSPSI.2021.7.02

Paasi, A. (2021), Foreword. In: Banini T., Ilovan O.-R. (eds.), Representing Place/Territorial Identity in Europe. Discourses, Images, and Practices. GeoJournal Library, vol. 127. Springer, Cham, V-IX.

Purici Șt., Mareci Sabol H. (2021), "Built to last". Defining identity by the statues of Chernivtsi. Journal of Settlements and Spatial Planning, Special Issue 7, 5164. DOI: 10.24193/JSSPSI.2021.7.04

Răcăşan B. S., Egresi I. (2019), Tourism, branding and territorial identity in the rural space. Local authorities' perspective. Territorial Identities and Development, 4(2), 18-38. DOI: 10.23740/TID220192

Territorial Identities and Development Research Centre (TIDRC) (2020), Research Directions. http://itd.territorial-identity.ro/en/aboutus/. Accessed on 15.06.2021.

Tobiasz-Lis P., Wójcik M. (2021), "The village as a place of...”. Anchoring the territorial identity of the countryside. Examples from Poland. Journal of Settlements and Spatial Planning, Special Issue 7, 6572. DOI: 10.24193/JSSPSI.2021.7.05

Zotic V., Alexandru D.-E. (2015), Operational structures in urban and rural strategic development. Journal of Settlements and Spatial Planning, 6(2), 107-120. 